\title{
Eksplorasi Pemahaman Siswa pada Materi Perbandingan Senilai Menggunakan Konteks Cerita di SMP
}

\author{
Dewi Hamidah ${ }^{1}$ *, Ratu Ilma Indra Putri ${ }^{2}$, Somakim ${ }^{3}$ \\ ${ }^{1}$ Program Studi Tadris Matematika, STAIN Kediri, Jalan Sunan Ampel No. 7 Kediri, 64127, Indonesia. \\ ${ }^{2}$ Jurusan Pendidikan Matematika, Universitas Sriwijaya Palembang \\ ${ }^{3}$ Jurusan Pendidikan Matematika, Universitas Sriwijaya Palembang \\ * E-mail: dewi.hamidah@gmail.com
}

\begin{abstract}
ABSTRAK
Artikel ini berfokus pada eksplorasi pemahaman siswa dalam mengidentifikasi informasi atau hal-hal mengenai konsep perbandingan melalui cerita atau permasalahan serta untuk mengetahui sejauh mana siswa memaknai arti perbandingan senilai. Penelitian ini merupakan desain riset yang menggunakan pendekatan PMRI (Pendidikan Matematika Realistik Indonesia) dengan cerita sebagai konteks awal pembelajaran. Subjek penelitian ini adalah siswa kelas VII pada salah satu Sekolah Menengah Pertama di Palembang. Hasil penelitian menunjukkan bahwa penggunaan konteks cerita dapat membantu siswa mampu mengidentifikasi informasi atau hal-hal mengenai konsep perbandingan dan memahami arti perbandingan senilai. Penggunaaan cerita sebagai konteks awal pembelajaran dapat memberikan pengaruh yang positif pada pembelajaran matematika yang lebih menyenangkan, dan dapat meningkatkan pemahaman konsep matematika yang dipelajari.
\end{abstract}

Kata kunci: Perbandingan Senilai, PMRI, Cerita

\section{Exploration of Students' Understanding on Direct Proportion Concept Using Story as a Context in Middle School}

\begin{abstract}
This paper focused on exploration students' understanding to identify the information or anything about direct proportion concept by story or problem and to know how far the students comprehend about the meaning of direct proportion. The research is design research used PMRI approach with a Legend Story as a context of the starting learning. The subjects are 6 students $7^{\text {th }}$ grade from a Middle School in Palembang. The result showed the use of legend story as context can help the students to identify the information or anything about direct proportion concept by story or problem and to know how far the students comprehend about the meaning of direct proportion as well. The use of story as the starting learning can give positive effects for the learning mathematics more fun and increase the students' understanding on the mathematics concept learned.
\end{abstract}

Keywords: Direct Proportion, PMRI, The Story

\section{Pendahuluan}

Dalam kehidupan sehari-hari, kita tidak terlepas dari aktivitas yang melibatkan matematika. Tanpa disadari, matematika menjadi bagian dari hidup manusia. Terlepas dari itu, matematika juga menjadi pelajaran yang harus dipelajari pada jenjang Sekolah Dasar hingga Sekolah Menengah Atas. Namun tidak sedikit siswa yang mengalami kesulitan belajar 
pada bidang yang banyak berkaitan dengan angka-angka ini. Atiqa, Y. dan Kusrini [1] mengatakan, kendalanya adalah matematika memiliki karateristik yaitu mempunyai objek yang bersifat abstrak, sehingga dapat menyebabkan banyak siswa kesulitan mempelajari matematika.

Salah satu konsep matematika yang sering digunakan dalam kehidupan sehari-hari adalah perbandingan. Secara matematika perbandingan berarti sebuah pernyataan kesamaan antara dua rasio yang biasanya ditulis sebagai $\frac{a}{b}=\frac{c}{d}[2,3]$. Anak-anak maupun dewasa kurang mengerti konsep perbandingan walaupun mereka sering menggunakannya, misalnya dalam transaksi jual-beli. Capon dan Kuhn [2] mengatakan bahwa banyak orang dewasa tidak menunjukkan penguasaan terhadap konsep perbandingan.

Sebelum mempelajari konsep perbandingan senilai, siswa harus telah lebih dahulu memahami konsep perbandingan. Perbandingan adalah hubungan atau relasi antara dua kuantitas tertentu, sedangkan perbandingan senilai adalah pernyataan tentang dua rasio yang sama [4]. Konsep perbandingan senilai juga dapat ditemukan pada permasalahan pembuatan makanan atau resep makanan, misalnya perbandingan banyaknya tepung dan gula. Tanpa disadari bahwa konsep perbandingan senilai ini sangat dekat dalam kehidupan sehari-hari. Namun demikian, pemahaman konsep ini oleh siswa, masih sering mendapatkan kesulitan dalam proses penerimaan pengetahuannya. Menurut Pertiwi [5], siswa masih mengalami kesulitan dalam mengerjakan soal perbandingan. Pendapat tersebut didukung oleh Tiffani [6], bahwa siswa masih sering mengalami kesulitan untuk menyelesaikan permasalahan perbandingan senilai dan perbandingan berbalik nilai.

Dari berbagai jenis buku pelajaran matematika kelas VII yang peneliti temukan bahwa pembelajaran mengenai perbandingan senilai di sekolah diajarkan langsung pada algoritma dari materi tersebut. Pendekatan seperti ini dirasa kurang tepat karena dapat menyebabkan siswa memperoleh konsep yang kurang jelas. Hal ini sejalan dengan pernyataan Zulkardi [7], mengatakan bahwa berbagai buku matematika di Indonesia mengandung seperangkat peraturan dan algoritma; buku-buku tersebut kurang aplikasi berupa pengalaman nyata bagi siswa yang membacanya. Hal ini menyebabkan pembelajaran di kelas menjadi tidak bermakna. Siswa diajarkan pada hal-hal yang bersifat abstrak menjadikan siswa bosan dalam proses pembelajaran.

Seringkali diungkapkan bahwa menurut paradigma baru pendidikan peran guru harus diubah, yaitu tidak sekedar menyampaikan materi pelajaran kepada para siswanya, tetapi mampu menjadi mediator dan fasilitator [8]. Pembelajaran yang terpusat pada guru atau satu arah akan menghasilkan siswa yang kurang kritis dan kreatif. Peran guru sebagai mediator dan fasilitator akan menjadikan pembelajaran matematika lebih bermakna. Sehingga, menjadi guru harus mampu memahami pengalaman belajar seperti apa yang sesuai dengan kebutuhan siswa. Selain itu, guru diharapkan mampu berinteraksi dengan siswa secara baik dan mempunyai pikiran yang fleksibel untuk dapat menghargai pendapat siswa. Pemikiran guru tidak boleh saklek hanya terpusat pada satu strategi saja, khususnya dalam pembelajaran matematika, oleh karena biasanya satu permasalahan dapat diselesaikan oleh lebih dari satu strategi.

Telah diketahui bersama bahwa sudah banyak pendekatan yang digunakan dalam pembelajaran matematka, salah satunya adalah pendekatan kontekstual. Pembelajaran dalam tautan atau biasa disebut dengan pembelajaran kontekstual merupakan sistem pembelajaran yang menghubungkan pengetahuan yang sudah dimiliki dengan pengetahuan baru sehingga seseorang mengetahui makna dari apa yang dipelajarinya. Dalam mengajar matematika, guru dapat menggunakan konteks yang sesuai dengan materi yang akan dibahas. Dengan adanya konteks, siswa mampu menghubungkan antara pelajaran di sekolah dengan kegiatan sehari- 
hari mereka. Pembelajaran yang demikian memungkinkan siswa untuk menemukan makna dari pelajaran di sekolah.

Pendidikan Matematika Realistik Indonesia (PMRI) merupakan salah satu pendekatan pembelajaran matematika yang diadopsi dari Realistic Mathematics Education (RME). Dalam RME, guru memfasilitasi siswa untuk menemukan konsep matematika yang riil bagi siswa. Pembelajaran tidak berpusat pada guru melainkan pada siswa, karena kontribusi siswa sangat penting dalam memperoleh pengetahuan baru. Dengan demikian pembelajaran matematika menjadi lebih bermakna (meaningful) sehingga pada akhirnya terjadi pencapaian pembelajaran yang efektif. Hans Freudhental berpendapat bahwa mathematics as human activity, sehingga siswa bukan menjadi penerima pasif tetapi siswa harus diberikan kesempatan untuk menemukan kembali matematika melalui bimbingan orang dewasa [9].

Dalam PMRI, konteks digunakan sebagai titik awal pengembangan konsep matematika. Konteks disini tidak hanya yang bersifat riil atau nyata tetapi juga sesuatu yang dapat dibayangkan oleh siswa. Misalnya jika siswa belum pernah naik pesawat namun siswa pernah melihatnya di media elektronik maupun media cetak sehingga siswa mampu membayangkan wujud pesawat maka hal itu dapat dikatakan sebagai konteks. Dengan adanya konteks, pembelajaran matematika menjadi lebih interaktif, siswa mampu menyatakan persetujuan atau ketidaksetujuan, menguraikan pendapat sesuai logikanya, serta memberikan penyelesaian alternatif jika ada.

Konteks kehidupan sehari menjadi dasar pada proses pembelajaran PMRI agar matematika menjadi bermakna bagi siswa sehingga matematika selalu menjadi bermakna bagi siswa. Triyani [10] mengatakan penggunaan cerita dalam pembelajaran matematika telah ditemukan bahwa hal itu memberikan pengaruh yang positif pada pembelajaran matematika yang lebih bermakna, menyenangkan, dan dapat meningkatkan pemahaman konsep matematika yang dipelajari. Pada penelitian ini, yang menjadi konteks awal pembelajaran perbandingan senilai adalah cerita rakyat Legenda Candi Prambanan. Dalam cerita tersebut diketahui informasi bahwa Putri Roro Jonggrang meminta Raden Bandung Bondowoso untuk membangun 1000 candi sebagai syarat yang harus dipenuhi agar dapat mempersuntingnya. Namun Raden Bandung Bondowoso dipermainkan oleh Putri Roro Jonggrang sehingga sampai pagi tiba hanya 999 candi yang mampu dibangun oleh para jin suruhan Raden Bandung Bondowoso. Dari sini terlihat bahwa situasi pada cerita tersebut dapat dikaitkan pada konsep perbandingan. Diharapkan melalui cerita, siswa bisa lebih termotivasi dan tertarik dalam mempelajari matematika khususnya tentang perbandingan senilai.

Tujuan dari penelitian ini adalah mengeksplorasi pemahaman siswa dalam mengidentifikasi informasi atau hal-hal mengenai konsep perbandingan melalui cerita atau permasalahan serta untuk mengetahui sejauh mana siswa memaknai arti perbandingan senilai.

\section{Metode}

Metode penelitian ini adalah design research yaitu suatu metode penelitian yang bertujuan mengembangkan local instructional theory dengan kerjasama antara peneliti dan guru untuk meningkatkan kualitas pembelajaran [11]. Sedangkan menurut Plomp [12], mengatakan bahwa design research adalah suatu kajian sistematis tentang merancang, mengembangkan, dan mengevaluasi intervensi pendidikan (seperti program dan bahan pembelajaran, produk dan sistem) sebagai solusi untuk memecahkan masalah yang kompleks dalam praktek pendidikan.

Peneliti mengumpulkan data dari berbagai sumber, untuk mendapatkan visualisasi terhadap penguasaan siswa secara menyeluruh terhadap materi perbandingan senilai. Data dikumpulkan melalui dokumen berupa foto, video rekaman, observasi, wawancara, dan hasil lembar kerja Selanjutnya, data yang diperoleh dan dianalisis menggunakan pendekatan 
deskriptif kualitatif. Bersama guru dan observer, peneliti mendiskusikan data yang terkumpul guna menghindari subjektifitas peneliti.

Subjek penelitian adalah siswa kelas VII pada salah satu Sekolah Menengah Pertama di Palembang yang terdiri dari 3 siswa laki-laki dan 3 siswa perempuan.

\section{Hasil dan Pembahasan}

Terdapat dua aktivitas pembelajaran yang diimplementasikan pada penelitian ini yaitu mengidentifikasi informasi atau hal-hal mengenai konsep perbandingan melalui cerita atau permasalahan dan memahami arti perbandingan senilai.

Berikut pemaparan deskripsi aktivitas pada lintasan pembelajaran serta analisis pemahaman siswa mengenai konsep perbandingan dan perbandingan senilai.

Aktivitas pertama memiliki tujuan pembelajaran yaitu siswa mampu mengidentifikasi informasi atau hal-hal mengenai konsep perbandingan melalui cerita atau permasalahan. Berikut pemaparan pada aktivitas 1 .

Pada awal pembelajaran aktivitas 1 , berdasarkan pretest yang telah mereka selesaikan pada pertemuan sebelumnya, guru bertanya kepada siswa tentang materi apa yang akan mereka pelajari hari ini, dan apakah siswa mengetahui materi yang akan dipelajari berdasarkan soalsoal pretest. Kemudian guru bertanya satu per satu kepada seluruh siswa, semuanya menggelengkan kepalanya dan ada siswa yang masih malu mengungkapkan pendapatnya. Lalu guru bertanya kembali, apakah waktu SD mereka pernah belajar perbandingan atau tidak. Beberapa siswa menjawab iya, lainnya menjawab tidak.

Kemudian guru kembali bertanya tentang contoh pernyataan perbandingan, dan siswa kembali diam. Agar siswa bisa mengingat kembali materi tentang perbandingan, guru memberi pertanyaan berapa jumlah siswa laki-laki dan perempuan di kelas, dan berapakah perbandingannya.

Guru : Misal, di kelas ini ada berapa siswa laki-laki dan perempuan ya? Perbandingannya berapa?

Siswa : 3 banding 3

Guru : kalau perbandingan jumlah siswa perempuan dan seluruh siswa, berapa?

Afif : tiga banding enam

Vera : tiga per enam $\left(\frac{3}{6}\right)$

Lalu guru meminta siswa kembali untuk memberikan contoh perbandingan lainnya. Akhirnya siswa sudah berani mengungkapkan pendapatnya dengan memberikan contohcontoh pernyataan perbandingan sehari-hari. Dari contoh-contoh yang disebutkan siswa tadi kemudian guru menjelaskan tentang pentingnya mempelajari perbandingan karena sering kita gunakan dalam kehidupan sehari-hari. Untuk mengetahui sejauh mana pemahaman siswa mengenai perbandingan, guru bertanya mengenai umur dan tinggi badan seorang siswa kemudian menanyakan apakah umur dan tinggi badan dapat dibandingkan. Hasilnya, ada siswa yang telah paham mengenai perbandingan walau tidak sedikit yang belum mengerti. Berikut kutipan percakapannya.

Guru : sekarang umur afif berapa?

Afif: $12 \ldots$

Guru : tingginya?

Afif : gak tau... dulu $123 \mathrm{~cm} \ldots$

Guru : bisa gak kalau dibandingkan umur dengan tinggi badan?

Afif dan Rohman : gak bisa... 


\section{Guru : kenapa?}

Siswa : diam (menggelengkan kepala)

Afif dan Rohman mengatakan bahwa umur dan tinggi badan tidak dapat dibandingkan. Namun ketika ditanyakan alasannya, siswa tersebut masih belum mampu mengungkapkannya mengapa umur dan tinggi badan tidak bisa dibandingkan. Guru belum memberikan alasannya kepada siswa dengan harapan di akhir aktivitas siswa akan menemukan sendiri alasannya.

Setelah guru mengingatkan kembali contoh-contoh pernyataan perbandingan yang mereka telah pelajari di SD, guru juga menanyakan pengetahuan siswa tentang cerita Legenda Candi Prambanan. Guru bertanya apakah waktu SD pernah belajar sejarah? Apakah siswa pernah mendengar cerita legenda Candi Prambanan ?. Hanya ada satu siswa yang mengatakan pernah namun siswa tersebut mengetahuinya dari siaran di televisi yang pernah menayangkan film cerita Legenda Candi Prambanan.

Lalu guru membagi siswa menjadi dua kelompok yang setiap kelompoknya terdiri dari 3 orang, dan memberikan Lembar Aktivitas Siswa (LAS) kepada masing-masing kelompok. Sebelum mengerjakan LAS, siswa mendengarkan rekaman cerita legenda Candi Prambanan, seluruh siswa diminta mendengarkan dan mencatat hal-hal atau informasi penting yang berhubungan dengan perbandingan. Selesai mendengarkan cerita, siswa ditanya apakah dalam cerita tersebut terdapat pernyataan yang bisa dijadikan permasalahan perbandingan atau yang dapat dibandingkan. Guru menstimulasi siswa untuk berpikir sampai salah satu kelompok mengatakan ada dan kelompok lainnya diminta untuk menanggapinya. Mereka diminta menuliskannya pada nomor pertama di Lembar Aktivitas Siswa (LAS) dan selanjutnya mengerjakan soal-soal yang terdapat di LAS. Setelah menyelesaikan LAS, guru membimbing siswa untuk mendiskusikan jawaban mereka.

Pada soal pertama, ketika dua kelompok diminta menuliskan jawabannya di papan tulis, kelompok perempuan menuliskan perbandingan dengan menggunakan titik dua (:) sedangkan kelompok laki-laki menggunakan bentuk pecahan. Begitu juga saat mendiskusikan soal nomor 4, dua kelompok memiliki jawaban berbeda. Kelompok laki-laki mengatakan bahwa pernyataan 3, 5, 8 bukan perbandingan alasannya karena satuannya tidak sama sedangkan kelompok perempuan menjawab hanya pernyataan 3 saja yang bukan pernyataan perbandingan dengan alasan yang tidak disebutkan.

Di akhir pembelajaran guru bertanya kepada siswa tentang soal pada lembar aktivitas yang menanyakan apakah pernyataan tersebut dapat ditentukan nilai perbandingannya atau tidak. Dua dari kelompok laki-laki telah memahami jawaban dan alasannya. Oleh karena itu guru meminta kelompok tersebut menjelaskan jawabannya kepada kelompok lainnya sehingga disini terjadi diskusi kelas dan siswa tersebut mengatakan bahwa "karena satuannya berbeda".

Setelah semua soal dibahas, maka guru menutupnya dengan menanyakan kesimpulan yang dapat diambil dari pembelajaran hari ini. Kesimpulannya yaitu penulisan nilai perbandingan boleh menggunakan titik dua (:), bentuk pecahan maupun dalam bentuk kalimat ; kemudian dua hal yang tidak bisa dibandingkan apabila satuannya tidak sama.

Dari pemaparan di atas, refleksi dari aktivitas 1 adalah sebagai berikut.

Kurang interaktifnya kelompok perempuan agak menyulitkan guru ketika ingin mengetahui jawaban dan alasan siswa. Hal ini kemungkinan karena mereka masih malu dalam menyampaikan pendapat. Pada pertemuan berikutnya diharapkan seluruh siswa berani menyampaikan pendapatnya tidak hanya dalam diskusi kelompok namun juga saat diskusi kelas.

Dari deskripsi aktivitas 1 di atas, peneliti menganilisis hasil penelitian secara restropektif sebagai berikut. 
Pada aktivitas ini, konteks Legenda Candi Prambanan dimunculkan sebagai starting point pembelajaran. Pada nomor-nomor yang menanyakan nilai perbandingan, siswa telah mampu menuliskannya dengan benar. Dua kelompok memliki cara penulisan yang berbeda, hal ini sesuai dengan dugaan awal peneliti. Kelompok perempuan menuliskannya dalam bentuk pecahan dan kelompok laki-laki menuliskannya menggunakan titik dua (:). Namun pada soal yang menanyakan apakah pernyataan yang diberikan dapat dicari nilai perbandingannya, siswa belum memahaminya dengan baik. Ketika guru menanyakan "kenapa pernyataan ketiga bukan perbandingan ?", salah

satu siswa menjawab karena satuannya berbeda. Tetapi siswa terkecoh pada pernyataan yang memberikan satuan luas $\left(\mathrm{m}^{2}\right)$ dan panjang $(\mathrm{m})$. Kurangnya ketelitian atau pemahaman konsep yang kurang mengakibatkan siswa menjawab pernyataan tersebut dapat dicari perbandingannya.

Setelah melakukan aktivitas 1, agar siswa dapat memahami arti perbandingan senilai maka dilakukan aktivitas 2. Deskripsi pembelajaran pada aktivitas 2 dipaparkan sebagai berikut.

Ketika memulai pembelajaran, guru bertanya tentang materi pada pertemuan sebelumnya yaitu perbandingan. Siswa diminta menyebutkan yang termasuk pernyataan perbandingan. Siswa bekerja dengan teman dalam satu kelompok dan tiap kelompok terdiri dari empat sampai lima siswa. Guru membagikan Lembar Aktivitas Siswa. Setiap kelompok diberikan gambar-gambar candi dengan ukuran yang berbeda-beda.

Siswa diminta mengelompokkan candi-candi tersebut ke dalam kelompok yang "kelihatan mirip". Kelompok laki-laki dan perempuan mengatakan ada 3 kelompok. Lalu guru bertanya apakah betul ada 3 kelompok ?, selanjutnya siswa diminta mengukur lebar dan tinggi candi menggunakan penggaris dan mencatat datanya sesuai dengan kelompoknya di Lembar Aktivitas Siswa nomor .

Ketika siswa telah selesai mengukur dan mencatat data dari gambar candi-candi tersebut, guru bertanya pada salah satu kelompok mengenai alasan siswa. Seluruh siswa mengelompokkannya berdasarkan pengamatan visual. Berikut jawaban salah satu siswa tersebut.

Guru : kenapa yang ini satu kelompok?

Siswa : karena gambarnya samo, karena lebarnya samo, tingginya jugo samo...

Kemudian agar siswa lebih peka lagi atas alasan dalam mengelompokkan candi, guru mengajak siswa untuk memperhatikan data yang telah dicatat. Guru meminta siswa juga memperhatikan datanya, dan ada siswa yang sadar bahwa candi dalam satu kelompok memiliki rasio lebar dan tinggi yang senilai. Di bawah ini merupakan percakapan guru dan siswa.

Guru : coba perhatikan lebar dan tinggi candi yang sekelompok?

Bintang : ohh, rasio

Guru : kenapa rasionya?

Bintang : bisa dibandingkan...

Afif : naahhh, pucuknyo perkalian duo bawahnya perkalian tigo... (Lihat Gambar 1)

Bintang : ohh iyooo... satu kali empat dibagi duo... (sambil menunjuk lembar aktivitas siswa)

Guru : coba perhatikan kelompok yang lainnya... 


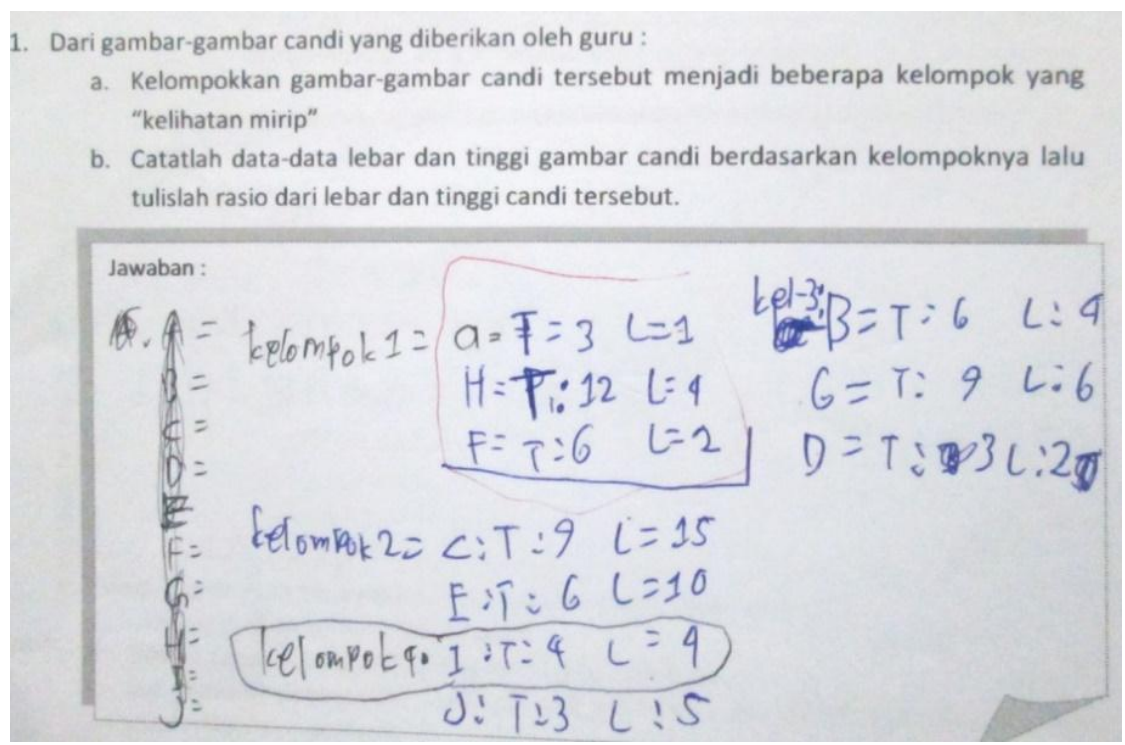

Gambar 1. Data Lebar dan Tinggi Candi Salah Satu Kelompok

Ketika salah satu siswa mencatat dan memperhatikan kelompok yang terdiri dari 4 candi, tiba-tiba siswa tersebut sadar dan mengatakan "ada empat kelompok ini...". Dengan antusias guru bertanya lagi, "Mengapa ada empat kelompok?" siswa tersebut menjawab "karena yang satu dewean" (dewean berarti sendirian dalam bahasa Palembang). Kemudian guru menanyakan kepada siswa lain untuk menanggapi jawaban temannya tersebut tetapi mereka juga belum menyadari bahwa harusnya terdapat empat kelompok. Namun guru terus membimbing dan menstimulasinya agar siswa tersebut mampu mengungkapkan alasannya. Guru meminta siswa memperhatikan satu per satu data tinggi dan lebar setiap candi apakah bisa dibandingkan atau tidak dengan yang lainnya. Ketika sampai pada candi berlabel I yang lebarnya $4 \mathrm{~cm}$ dan tingginya $4 \mathrm{~cm}$, salah satu siswa (Bintang) langsung mengatakan "Afif bener...". Akhirnya siswa tersebut mampu menyatakan alasan kenapa satu candi tidak masuk pada kelompok lainnya. Guru menanyakan alasannya, yang ditunjukkan pada percakapan berikut.

Guru : apa yang benar? berarti ada berapa kelompok?

Siswa : empat...

Guru : kenapa?

Siswa : karena tidak bisa dibagi... karena tidak sama...

Guru : apanya yang tidak sama?

Siswa : rasionya...

Kemudian guru melanjutkan pertanyaan,

Guru : jadi hubungannya? rasionya?

Afif : persamaan kali...

Bintang : rasio itu persamaan nilai... kan idak katek yang sama idak katek kelompok

Guru : berarti, rasionya?

Afif : sama...

Bintang : senilai...

Siswa lainnya : senilai...

Afif : sama dan senilai...

Guru : kalau sama itu persis, kalau yang seperti ini namanya?

Siswa : senilai...

Guru : nah, senilai bisa juga disebut ekuivalen. Pernah dengar?

Siswa : belum... (sambil menggelengkan kepala) 
Dari percakapan tersebut maka siswa lainnya pada akhirnya menyadari bahwa terdapat 4 kelompok candi. Setelah itu, guru meminta siswa kembali mengerjakan soal nomor 2 dan seterusnya di Lembar Aktivitas Siswa. Guru bertanya apakah siswa masih mengingat perbandingan apa saja yang mereka tuliskan pada jawaban nomor 1 di LAS yang pertama. Siswa diminta menuliskannya kembali lalu mencari rasionya yang senilai.

Selanjutnya siswa menyelesaikan LAS secara berkelompok. Guru mengingatkan siswa tentang hal-hal atau masalah-masalah yang telah mereka kumpulkan dan tulis pada Aktivitas I kemudian meminta siswa menentukan rasionya. Masing-masing kelompok diminta menuliskan rasio yang ekuivalen dari masalah-masalah tersebut sebanyak mungkin di papan tulis, lalu mendiskusikan jawaban mereka dengan kelompok lainnya. Mereka juga diminta untuk menentukan rasio yang paling sederhana dari perbandingan tersebut. Setelah selesai mengerjakan Lembar Aktivitas, tiap kelompok mempresentasikan hasil kerjanya dan kelompok lain menanggapinya. Guru menjembatani proses jalannya diskusi kelas.

Dari pemaparan di atas, diperoleh refleksi dari aktivitas 2 adalah sebagai berikut.

Untuk meningkatkan kesadaran siswa pada jawaban-jawaban yang diminta, sebaiknya guru terus bertanya mengenai hal-hal yang nantinya siswa tahu kesalahannya. Guru menstimulasi siswa agar siswa akhirnya mengkonstruk sendiri jawaban mereka. Seperti halnya pada aktivitas mengelompokkan gambar-gambar candi yang kelihatan "mirip". Setelah siswa mencatat data panjang dan tingginya, siswa diminta memperhatikan hubungan-hubungan rasio panjang dan tingginya dalam satu kelompok maupun dengan kelompok lainnya. Pada akhirnya siswa pun mengerti makna senilai dari sebuah perbandingan.

Kemudian untuk menghubungkan dan mengevaluasi konjektur dari data yang diperoleh serta untuk menghindari bias sistematik, analisis retrospektif dari aktivitas 2 adalah sebagai berikut. Sebelum memasuki aktivitas kedua, guru kembali mengingatkan materi yang telah dipelajari pada aktivitas sebelumnya. Guru meminta siswa memberikan contoh permasalahan perbandingan dan menyebutkan nilai perbandingannya. Siswa telah mampu memberikan contoh dan nilai perbandingannya dengan benar. Aktivitas ini diawali dengan kegiatan menentukan candi-candi mana yang kelihatan mirip lalu mengelompokkannya. Sebelum mengukur, siswa ditanyakan berapa kelompok candi yang kelihatan mirip, seluruh siswa mengatakan tiga dengan alasan karena gambar, lebar, dan tingginya sama. Namun setelah mengukur dan mencatat datanya, ada satu siswa yang sadar bahwa ada satu candi yang berbeda rasio ukuran panjang dan tingginya sehingga siswa tersebut mengatakan ada empat kelompok candi. Guru memintanya untuk menjelaskan kepada siswa lainnya sehingga mereka memiliki kesempatan untuk mendapatkan pengetahuan baru dari temannya. Dia mengatakan bahwa ukuran lebar dan tinggi candi berlabel I berbeda dari yang lainnya sehingga candi tersebut tidak masuk dalam kelompok lainnya. Yang dimaksud berbeda disini adalah rasio lebar dan tingginya yang tidak senilai dari kelompok candi yang lain. Disini siswa akhirnya sadar akan kekeliruan mereka sebelumnya.

Pada lembar aktivitas, siswa telah mampu menentukan rasio yang ekuivalen dari perbandingan-perbandingan yang diberikan. Penulisan rasio ekuivalen siswa sesuai dengan dugaan guru, ada siswa yang menuliskannya dalam bentuk pecahan dan ada juga yang menuliskannya menggunakan titik dua (:). Namun ada satu permasalahan dimana siswa belum mampu mengungkapkannya dengan benar yaitu ketika siswa ditanyakan mengenai bilangan non-integer ratio. Dengan melihat hasil kerja lembar aktivitas siswa, kekeliruan ini terjadi karena siswa kurang memperhatikan pada apa yang ditanyakan soal.

\section{Kesimpulan}

Dari pemaparan di atas, diperoleh kesimpulan bahwa, (1) Melalui informasi ataupun pernyataan mengenai cerita, siswa dapat memahami konsep perbandingan dengan 
membandingkan dua nilai; (2) Dengan menggunakan manipulatif gambar candi dengan ukuran yang berbeda-beda, siswa mampu mengelompokkannya berdasarkan rasio lebar dan tinggi yang senilai; (3) Penggunaan konteks cerita dapat membantu siswa dalam mengidentifikasi informasi atau hal-hal mengenai konsep perbandingan dan memahami arti perbandingan senilai.

\section{DAFTAR PUSTAKA}

[1] Atiqa, Y. \& Kusrini. (2013). Pengaruh Pembelajaran Matematika Realistik Terhadap Memori Siswa Pada Sub Materi Perbandingan Senilai Dan Beralik Nilai Di Kelas VII SMP Negeri 5 Tuban. Jurnal MathEdunesa, 2 (1). Diakses dari http://id.portalgaruda.org/index.php?ref=browse\&mod=viewarticle \&article $=65277$.

Tanggal 22 Agustus 2017

[2] Pedagogical Content Knowledge (PCK) Tools - The EI Paso Collaborative for Academic Exellence, Consortium for Policy Research in Education (CPRE), \& The Consortium for Achievement in Mathematics and Science (CAMS). Proportional Reasoning : Student Misconceptions and Strategies for Teaching. Diunduh pada 8 Mei 2012 dari http://www.epcae.org/uploads/documents/Proportional_Sept\%2020.pdf

[3] Tourniaire, F. \& Steven P. (1985). Proportional Reasoning : A Review of the Literature. Educational Studies in Mathematics, 16, 181-204. California: Group in Science and mathematics Education, Lawrence Hall of Science, University of California.

[4] Lanya, H. (2016). Pemahaman Konsep Perbandingan Siswa SMP Berkemampuan Matematika Rendah. Jurnal FKIP Universitas Madura, ¿IGMA, 2 (1), September 2016, hal. 20.

[5] Pertiwi, D.P. (2015). Penerapan Model Pembelajaran Quantum Teaching untuk Meningkatkan Hasil Belajar Siswa pada Materi Perbandingan di Kelas VII D SMP Negeri 9 Palu. Jurnal Elektronik. Tersedia: http://ejurnal.untad.ac.id. Diakses Tanggal 20 Oktober 2015.

[6] Tiffani, H. (2015). Profil Proses Berpikir Siswa SMP dalam Menyelesaikan Soal Perbandingan Berdasarkan Gaya Belajar dan Gaya Kognitif. [Online]. Skripsi Fakultas Keguruan dan Ilmu Pendidikan Universitas Muhammadiyah Surakarta. Jurnal Pendidikan, 1 (4). Tersedia: http://eprints.ums.ac.id /33195/. Diakses Tanggal 15 september 2015.

[7] Zulkardi. (2002). Developing A Learning Environment on Realistic Mathematics Education For Indonesian Student Teachers. Doctoral Thesis of Twente University. Enschede: Twente University.

[8] Hadi, S. (2005). Pendidikan Matematika Realistik. Banjarmasin: Tulip.

[9] Gravemeijer, K. (1994). Developing Realistic Mathematics Education. Utrecht: Technipress, Culemborg. 
[10] Triyani, S. (2012). Supporting Student's Ability in Understanding Least Common Multiple (LCM) Concept Using Storytelling. Journal on Mathematics Education, 3(2), 151-164. Palembang: IndoMS-JME.

[11] Gravemeijer, K., \& Van Eerde, D. (2009). Design Research as a Means for Building a Knowledge Base for Teaching in Mathematics Education. The Elementary School 109 (5). Chicago: The University of Chicago.

[12] Plomp. (2007). "Educational Design Research : An Introduction", dalam An Introduction to Educational Research. Enschede, Netherland : National Institute for Curriculum Development. 